Якимчук А. Ю. [1; ORCID ID: 0000-0002-5038-5215], д.е.н., професор, професор кафедри державного управління, документознавства та інформаційної діяльності

Кардаш О. Л. [1; ORCID ID: 0000-0002-6531-9165], к.е.н., доцент, доцент кафедри комп'ютерних технологій та економічної кібернетики

Якимчук О. Ф. [2; ORCID ID: 0000-0002-0960-8835], к.держ.упр., керівник групи розрахунків відділу бізнес-систем

${ }^{1}$ Національний університет водного господарства та природокористування, м. Рівне

${ }^{2} T O B$ «Рівненська обласна енергопостачальна компанія», м. Рівне

\title{
ОЦІНЮВАННЯ СТАНУ ЕКОЛОГІЧНОЇ БЕЗПЕКИ УКРАЇНИ НА ОСНОВІ ТАКСОНОМІЧНОГО АНАЛІЗУ
}

Концепція сталого розвитку ґарантує безпечне для життя і здоров'я населення навколишнє середовище. Оцінка стану навколишнього середовища підтверджується аналізом фактичних показників екологічної безпеки, що проведено у даному науковому дослідженні. Особлива увага відведена таким важливим показникам екологічної безпеки, як лісовідновлення, впровадження ресурсозберігаючих, маловідходних, безвідходних інновацій промисловими підприємствами України, витрати на збереження біорізноманіття i середовища існування, тощо. Запропоновано шляхи усунення недоліків у методиці оцінки рівня екологічної безпеки України. Проаналізовано стан екологічної безпеки у країнах Європейського Союзу та визначено нові тенденції ії удосконалення на національному рівні відповідно до концепції сталого розвитку. Здійснено аналіз основних індикаторів екологічної безпеки, задля приведення індикаторів до безвимірності проведено їх стандартизацію з урахуванням характеру їхнього впливу на інтегральний індикатор безпеки, розраховано таксономічний показник рівня екологічної безпеки, який комплексно характеризує вплив змін значень індикаторів на сукупний стан економічної безпеки України. У даній статті розглянуто перспективи підвищення рівня екологічної безпеки України відповідно до європейських нормативів і стандартів.

Ключові слова: держава; екологічна безпека; природні ресурси; сталий розвиток; інтегральний індикатор; таксономічний аналіз.

Постановка проблеми. У сучасних умовах пандемії й поширення коронавірусної інфекції, загострення соціально-економічних проблем, зростання масштабів господарської діяльності, інтенсифікації виробництва, науково-технічного прогресу відбувається порушення 
рівноваги в навколишньому природному середовищі. Саме тому питання забезпечення екологічної безпеки для громадян України набуло надзвичайної актуальності. Дотримання показників екологічної безпеки має істотне значення, особливо в сучасних умовах децентралізації влади, формування об'єднаних територіальних громад (ОТГ). Саме тому необхідність оцінювання інтегрального індикатора екологічної безпеки зростає у світі, $\epsilon$ стимулятором ініціалізації місцевих ініціатив, особливо в сучасних умовах децентралізації влади. Bce це сформувало мету, предмет та актуальність теми даного дослідження.

Аналіз останніх досліджень і публікацій. Питанням екологічної безпеки займалися О. Веклич, З. Бурик, І. Синякевич, О. Врублевська, В. Шевчук, Є.Романенко, Ю. Стадницький, П.Грицюк та ін. Проте саме у галузі формування індикаторів екологічної безпеки й таксономічного їх аналізу, оцінювання інтегрального індикатора екологічної безпеки достатньої уваги не приділялося. Bce це зумовило предмет цього дослідження.

Постановка завдання. Провести аналіз індикаторів екологічної безпеки, окремо за стимулятивними та дестимулятивними ознаками, розрахувати на їх основі інтегральне значення екологічної безпеки України за допомогою апарату таксономічного аналізу відповідно до концепції сталого розвитку, а також оцінити перспективи й можливості впровадження кращого закордонного досвіду задля підвищення рівня екологічної безпеки України.

Виклад основного матеріалу. Основи екологічної безпеки в Україні проголошені в Декларації про незалежність й на конституційному рівні, зокрема статтею 16 Конституції України, де йдеться, що екологічна безпека і екологічна рівновага на території України, збереження генофонду народу є обов'язком держави. Закон України «Про охорону навколишнього природного середовища» (ст. 50) також визначає екологічну безпеку як такий стан навколишнього природного середовища, при якому забезпечується попередження погіршення екологічної обстановки й виникнення небезпеки для здоров'я людей, що гарантує здійснення широкого комплексу взаємопов'язаних економічних, екологічних, політичних, технічних, організаційних, державно-правових та інших заходів. Відомо, що довкілля вважається безпечним за тієї умови, коли його стан відповідає встановленим законодавством критеріям, стандартам, лімітам і нормативам, що стосуються його чистоти (незабрудненості), ресурсомісткості (невиснаженості), екологічної стійкості, санітарних 
вимог, видового різноманіття, здатності задовольняти інтереси громадян.

Екологічна безпека - це такий стан навколишнього середовища, коли гарантується запобігання погіршення екологічної ситуації та здоров'я людини [5].

Екологічна безпека характеризує рівень захищеності життєво важливих інтересів людини, а також суспільства, довкілля й держави від реальних або потенційних загроз, зумовлених антропогенними чи природними чинниками. Оцінювання екологічної безпеки було проведено з використанням таксономічного аналізу системи індикаторів екологічної безпеки України.

у даному науковому дослідженні індикаторами екологічної безпеки було обрано показники, що характеризують ступінь захищеності від негативного екологічного впливу й відновлення навколишнього середовища України впродовж 2008-2019 рр. (табл. 1). Індикатори екологічної безпеки України виступають елементами сформованої матриці спостережень, мають різну розмірність та комплексно характеризують стан екологічної безпеки України.

Задля проведення індикаторів до безвимірності проведено їх стандартизацію 3 урахуванням характеру їхнього впливу на інтегральний показник безпеки. Індикаторами стимуляторами виступають: частка площі територій та об'єктів природнозаповідного фонду (показник заповідності), витрати на збереження біорізноманіття і середовища існування, площа природнозаповідного фонду, лісовідновлення, впровадження ресурсозберігаючих, маловідходних, безвідходних інновацій промисловими підприємства. Індикатори де стимулятори: викиди забруднюючих речовин у атмосферне повітря на душу населення, обсяг скидів зворотних вод, рубки лісу.

В результаті стандартизації була сформована матриця Z стандартизованих значень індикаторів екологічної безпеки України.

$Z=\left(\begin{array}{cccccccccccc}-1.24 & -0.32 & -0.78 & -1.02 & -0.95 & -0.78 & -0.19 & 0.81 & 0.54 & 1.18 & 1.32 & 1.44 \\ -1.33 & -0.57 & -0.91 & -0.84 & -0.88 & -0.62 & -0.27 & 1.03 & 0.99 & 1.52 & 0.98 & 0.91 \\ -2.03 & -1.34 & -0.76 & -0.38 & -0.09 & -0.03 & 0.20 & 0.39 & 0.97 & 0.97 & 0.97 & 1.16 \\ -1.22 & -1.21 & -0.65 & -0.26 & -0.04 & 0.13 & -0.79 & -0.59 & 0.02 & 1.48 & 1.48 & 1.55 \\ -1.71 & -1.57 & -1.12 & -0.44 & 0.04 & 0.32 & 0.44 & 0.46 & 0.50 & 0.62 & 1.25 & 1.20 \\ -0.67 & 1.98 & 0.24 & -0.53 & -0.34 & 0.33 & 1.03 & 0.35 & 0.86 & -0.42 & -1.46 & -1.36 \\ 1.84 & 1.19 & 0.68 & 0.59 & 0.11 & -0.37 & -0.48 & -0.43 & -0.11 & 0.07 & -1.44 & -1.65 \\ 0.63 & 0.50 & 0.49 & 0.34 & -0.03 & -0.62 & -1.25 & -1.12 & 2.19 & 0.62 & -0.64 & -1.10\end{array}\right)$ 
Таблиця 1

Основні індикатори, що характеризують екологічну безпеку України (2008-2019рр.)

\begin{tabular}{|c|c|c|c|c|c|c|c|c|c|c|c|c|c|}
\hline \multirow{2}{*}{$\begin{array}{l}\text { № } \\
\text { 3/C } \\
\end{array}$} & \multirow{2}{*}{ Індикатори екологічної безпеки } & \multicolumn{12}{|c|}{ Роки } \\
\hline & & 2008 & 2009 & 2010 & 2011 & 2012 & 2013 & 2014 & 2015 & 2016 & 2017 & 2018 & 2019 \\
\hline 1 & $\begin{array}{l}\text { Викиди забруднюючих речовин у } \\
\text { атмосферне повітря на душу } \\
\text { населення, кг/особу }\end{array}$ & 136,7 & 120,6 & 128,7 & 132,9 & 131,7 & 128,6 & 118,3 & 100,5 & 105,4 & 94,01 & 91,5 & 59,5 \\
\hline 2 & $\begin{array}{l}\text { Обсяг скидів зворотних вод, } \\
\text { млн м³ на рік }\end{array}$ & 8342 & 7381 & 7817 & 7725 & 7780 & 7440 & 7000 & 5343 & 5399 & 4715 & 5412 & 5500 \\
\hline 3 & $\begin{array}{l}\text { Частка площі територій та } \\
\text { об'єктів природно-заповідного } \\
\text { фонду (показник заповідності), \% }\end{array}$ & 5,04 & 5,4 & 5,7 & 5,9 & 6,05 & 6,08 & 6,2 & 6,3 & 6,6 & 6,6 & 6,6 & 6,7 \\
\hline
\end{tabular}

స̃ 


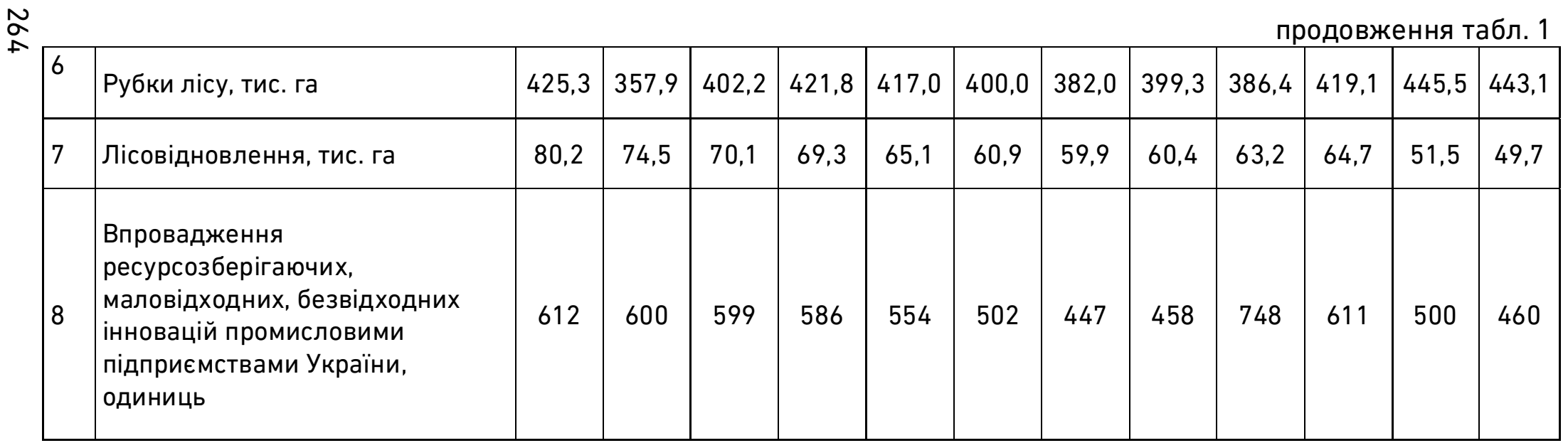


Формування вектора-еталона $P_{0}=\left(z_{01}, \ldots, z_{0 m}\right)$ проведено шляхом вибору зі стовпців матриці Z максимального значення для індикаторів-стимуляторів і мінімального - для індикаторівдестимуляторів.

$$
P_{0}=(-1.24,-1.33,1.16,1.55,1.25,-1.46,1.84,2.19)
$$

Значення вектора-еталона використані для розрахунку додаткових показників: відстані між спостереженнями та векторометалоном, середньої і граничної відстаней відхилень від еталону, рівня безпеки (табл. 2). Отримані відстані слугують основою для розрахунку показника рівня екологічної безпеки України.

Розрахований таксономічний показник рівня екологічної безпеки України протягом 2008-2019 рр. набував надзвичайно низьких значень у інтервалах 2008-2009 рр. (0,18-0,07), 20142015 pp. (0,14-0,11), 2018-2019 pp. (0,16-0,10), що відповідає небезпечному рівню безпеки. Лише у 2011-2012 рр. рівень екологічної безпеки України досяг кризового стану, що $є$ також досить загрозливим i потребує застосування комплексного механізму державного регулювання та ефективного впровадження системи екологічного контролю та моніторингу.

Динаміку зміни показника рівня екологічної безпеки України представлено на рис. 1.

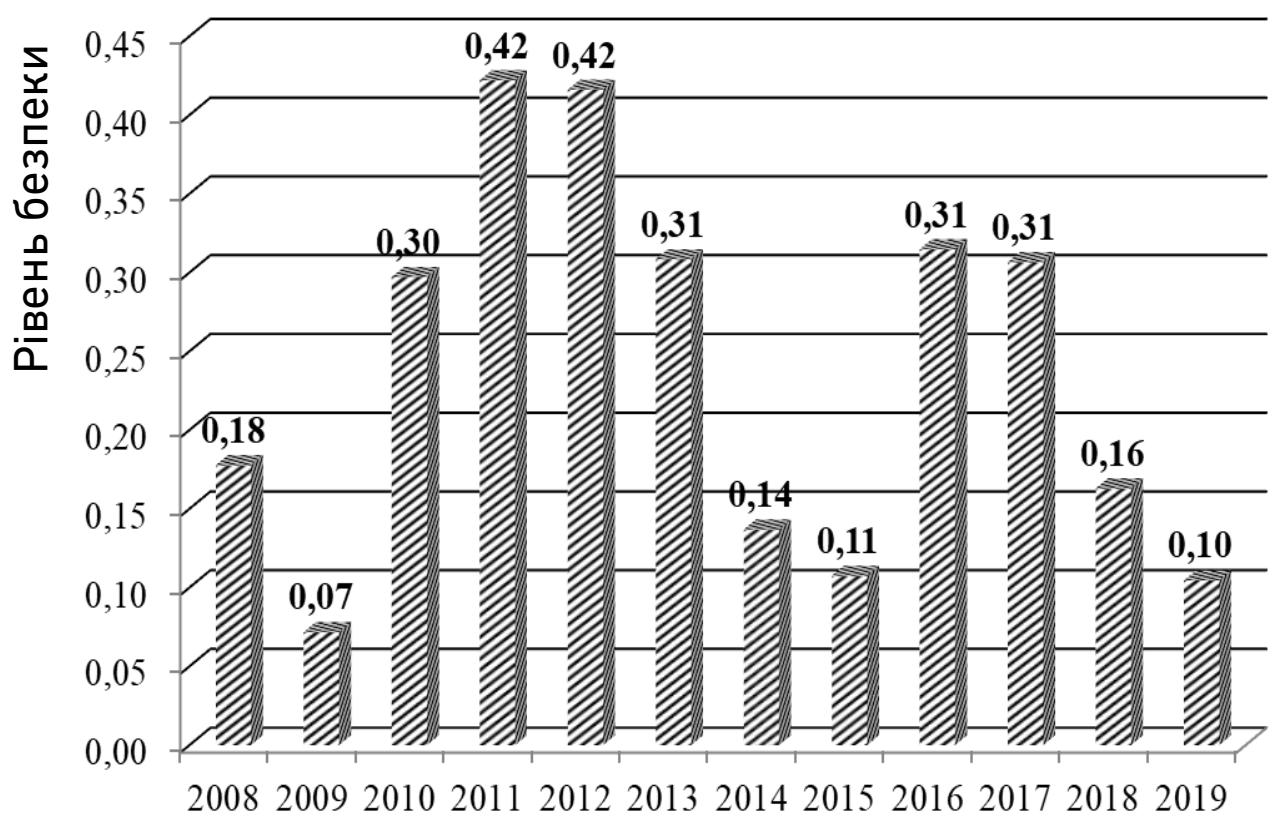

Рис. 1. Динаміка зміни інтегрального показника рівня екологічної безпеки України за 2008-2019 рр. 
Результати розрахунку таксономічного показника рівня екологічної безпеки України

\begin{tabular}{|c|c|c|c|c|c|c|c|c|c|c|c|c|c|}
\hline \multirow{2}{*}{$\begin{array}{l}\text { № } \\
3 / \pi\end{array}$} & \multirow[t]{2}{*}{ Назва показника } & \multicolumn{12}{|c|}{ Роки } \\
\hline & & 2008 & 2009 & 2010 & 2011 & 2012 & 2013 & 2014 & 2015 & 2016 & 2017 & 2018 & 2019 \\
\hline 1 & $\begin{array}{l}\text { Відстань } \\
\text { стандарти-зованими } \\
\text { значеннями } \\
\text { індикаторів } \\
\text { вектором еталону, } \\
C_{0 j}\end{array}$ & 5,44 & 6,14 & 4,65 & 3,82 & 3,86 & 4,58 & 5,71 & 5,91 & 4,53 & 4,59 & 5,54 & 5,93 \\
\hline 2 & $\begin{array}{l}\text { Середня відстань між } \\
\text { стандартизованими } \\
\text { значеннями } \\
\text { індикаторів і } \\
\text { вектором еталону, } \overline{C_{0}}\end{array}$ & \multicolumn{12}{|c|}{5,06} \\
\hline 3 & $\begin{array}{l}\text { Загальна відстань } \\
\text { між показниками та } \\
\text { еталоном, } C_{0}\end{array}$ & \multicolumn{12}{|c|}{6,62} \\
\hline 4 & $\begin{array}{l}\text { Відхилення } \\
\text { показників } j \text {-го року } \\
\text { від еталону, } d_{j}\end{array}$ & 0,82 & 0,93 & 0,70 & 0,58 & 0,58 & 0,69 & 0,86 & 0,89 & 0,69 & 0,69 & 0,84 & 0,90 \\
\hline 5 & $\begin{array}{ll}\text { Показник } & \text { рівня } \\
\text { безпеки, } K_{j} & \end{array}$ & 0,18 & 0,07 & 0,30 & 0,42 & 0,42 & 0,31 & 0,14 & 0,11 & 0,31 & 0,31 & 0,16 & 0,10 \\
\hline
\end{tabular}


Динаміка показника рівня екологічної безпеки України у 20082019 рр. є досить нестійкою, переважають значні коливання значень та пікові зниження у ряді років. Дана ситуація обумовлена значним антропогенним навантаження на довкілля, високим рівнем викидів забруднюючих речовин у атмосферне повітря на воду, великими площами вирубки лісів. Низьким рівнем характеризується застосування ресурсозберігаючих, маловідходних, безвідходних інновацій та природоохоронних технологій підприємствами України, малою часткою площі територій та об'єктів природно-заповідного фонду.

Завдання гарантування екологічної безпеки України повинні мати чітке концептуальне викладення і виступати інтегральним елементом стратегії соціально-економічного розвитку країни. Потребує запровадження система аналізу екологічної ситуації, прогнозування, планування і здійснення запобіжних заходів щодо ймовірних факторів шкідливого впливу на навколишнє природне середовище та здоров'я людей.

На планетарному рівні екологічні проблеми потребують особливої уваги, адже розвиток кризи в масштабах всієї планети призведе до руйнування системи життєзабезпечення людства і руйнування саморегуляційних механізмів біосфери. Сучасна екологічна криза пов'язана з іншими глобальними проблемами сьогодення, які можуть мати синергетичний ефект. Зокрема, екологічна проблема пов'язана із демографічною, харчовою, ресурсною, енергетичною, тероризмом тощо. Внаслідок взаємного посилення тих чи інших сучасних глобальних проблем людства, можливі різні фатальні сценарії розвитку планети Землі і людської цивілізації : ядерна зима, летальна пандемія, генетичне виродження, втрата цікавості до проблем тощо. Всі вони можуть призвести до незворотних змін в біосфері Землі, а від так - призвести до загибелі людської цивілізації.

Все це говорить про необхідність захисту навколишнього середовища і докорінної зміни відношення людей до природи, комплексного підходу до вирішення цих проблем. Єдиним шляхом збереження екологічної рівноваги в біосфері $\epsilon$ : обмежене споживання людиною природних ресурсів за рахунок створення мало- і безвідходних технологій, перехід на альтернативні ресурси тощо, та зменшення ступеня забруднення природного середовища. Безумовно, гарантія екологічної безпеки неможлива без вирішення ряду політичних (зброя масового знищення, тероризм тощо), економічних (економічна відсталість ряду країн, проблема освоєння 
ресурсів Світового океану тощо) та соціальних проблем (наркоманія, злочинність тощо), з врахуванням можливих стихійних лих. Особливої актуальності набуває міжнародне співробітництво в галузі охорони навколишнього середовища та забезпечення екологічної безпеки, адже вирішення більшості сучасних проблем людства можливе лише на рівні всього світу [2].

В Україні необхідно створити режим вільного переміщення всіх технологій, наукових досягнень у сфері використання природних ресурсів, контролю за станом довкілля, ресурсозбереженням, маловідходного або безвідходного виробництва, утилізації відходів, використання яких призводить до зниження антропогенного навантаження на довкілля. Це дозволить використовувати найновіші досягнення В галузі охорони природи всім державам без виключення, залучить до природоохоронної діяльності малорозвинені держави та включить до системи забезпечення екологічної безпеки максимальну кількість країн. Так, розвинені країни, виходячи зі своїх законів, правил і тактики, зобов'язуються сприяти обміну технологією 3 метою запобігання промисловим аваріям, забезпечення готовності до них і ліквідації їх наслідків (ст. 16 Конвенції про транскордонний вплив промислових аварій від 17 березня 1992 р.), здійснювати співробітництво 3 розробки й застосування нових, екологічно обґрунтованих, маловідходних технологій (ст. 10 Базельської конвенції).

Висновки. У останні роки в Україні, через військово-політичну нестабільність держави, простежується послаблення загального інтересу щодо оцінювання стану екологічної безпеки України. Нині знизила свою діяльність програма EC TACIS, згорнули свою роботу в Україні Фонд Сороса, фактично закрив свої програми MCOП (IUCN). Варто зазначити, що сьогодні, задля успішного вирішення поставлених перед людством завдань щодо збереження й відтворення природних ресурсів, запобігання змінам клімату, боротьби із коронавірусом необхідні поєднання зусиль урядових та неурядових організацій, широких верств населення всіх держав світу в контексті підвищення рівня екологічної безпеки в глобальному масштабі. У даному дослідження проведено оцінювання інтегрального індикатора екологічної безпеки України 3 використанням таксономічного аналізу. Як свідчать отримані результати, динаміка показника рівня екологічної безпеки України у 2008-2019 рр. є досить нестійкою, переважають значні коливання значень та пікові зниження за низку років впродовж досліджуваного періоду. Дана ситуація спричинена значним антропогенним навантаження на довкілля, високим рівнем викидів забруднюючих 
речовин у атмосферне повітря й скидами у водні об'єкти, великими площами вирубки лісів. Низьким рівнем характеризується застосування ресурсозберігаючих, маловідходних, безвідходних інновацій та природоохоронних технологій підприємствами України, малою часткою площі територій та об'єктів природно-заповідного фонду. Нині завдання гарантування екологічної безпеки України повинні на державному рівні отримати чітке концептуальне викладення і виступати інтегральним елементом стратегії соціальноекономічного розвитку країни. Потребує запровадження система аналізу екологічної ситуації, прогнозування, планування й здійснення запобіжних заходів щодо ймовірних факторів шкідливого впливу на навколишнє природне середовище та здоров'я людей.

1. Про охорону навколишнього природного середовища : Закон України від 25.06.91. Відомості Верховної Ради України. 1991, № 41 (08.10.91), ст. 546. 2. Стратегія державної екологічної політики України на період до 2020 року. Офіційний сайт Мінприроди України. URL: http://www.menr.gov.ua/ index.php/about/strategy (дата звернення: 29.12.2019). 3. Buryk Z., Bashtannyk V., Ragimov F. Economic growth: macroeconomic effects of Public Borrowings at the global level. Problems and Perspectives in Management. 2019. Volume 17, Issue 3. Pр. 169-183. 4. Синякевич І. М. Інструменти екополітики: теорія і практика. Львів : ЗУКЦ, 2003. 188 с. 5. Пухова У. М. «Природный капитал», как часть составляющего природных ресурсов. Фундаментальные исследования. 2008. № 2. С. 130-132. 6. Onyshchuk S., Buryk Z., Knysh P. Management of the economic potential of territories in the context of sustainable development: case of Ukraine Problems and perspectives in management. Business perspectives. 2019. Volume 17, Issue 4. Pp. 1325. 7. Плюта В. Сравнительный многомерный анализ в экономических исследованиях / пер. с польск. В.В. Иванова. М.: Финансы и статистика, 1989. 174 с. 8. Дідківська Т. В., Сверчевська І. А. Узагальнення золотої системи числення. Вісн. Житомир. держ. пед. ун-ту. 2003. № 11. С. 36-39. 9. Давидюк 0. О. Соціальна безпека: проблеми теоретичного аналізу та побудови системних показників. URL: http://www.cpsr.org.ua/ (дата звернення: 20.05.2020). 10. Індикатори стану екологічної безпеки держави. Аналітична записка. URL: http://old2.niss.gov.ua/articles/993. (дата звернення: 20.05.2020). 11. Павлова О. М., Купчак В. Р., Павлов К. В., Лагодієнко В. В. Формування та регулювання регіональних енергетичних систем: теорія, методологія та практика: монографія. Луцьк: СПД Гадяк Жанна Володимирівна, друкарня «Волиньполіграф», 2019. 346 с. $\quad$ 12. Павлов К. В., Павлова О. М., Коротя М.І. Регулювання діяльності регіональних газорозподільних підприємств України: монографія. Луцьк: СПД Гадяк Жанна Володимирівна, друкарня «Волиньполіграф», 2020. 256 с. 13. Pavlov K., Pavlova O., Kupchak V. Integral Indicators Based on Competitiveness Capacity Characteristics of Regional Real Estate Markets of Ukraine. Journal of Competitiveness. 2019. №11(3). C. 87108 https ://doi.org/10.7441/joc.2019.03.06 (дата звернення: 20.05.2020). 


\title{
REFERENCES:
}

1. Pro okhoronu navkolyshnoho pryrodnoho seredovyshcha : Zakon Ukrainy vid 25.06.91. Vidomosti Verkhovnoi Rady Ukrainy. 1991, № 41 (08.10.91), st. 546. 2. Stratehiia derzhavnoi ekolohichnoi polityky Ukrainy na period do 2020 roku. Ofitsiinyi sait Minpryrody Ukrainy. URL: http://www.menr.gov.ua/ index.php/about/strategy (data zvernennia: 29.12.2019). 3. Buryk Z., Bashtannyk V., Ragimov F. Economic growth: macroeconomic effects of Public Borrowings at the global level. Problems and Perspectives in Management. 2019. Volume 17, Issue 3. Pp. 169-183. 4. Syniakevych I. M. Instrumenty ekopolityky: teoriia i praktyka. Lviv : ZUKTs, 2003. 188 s. 5. Puhova U. M. «Prirodnyiy kapital», kak chast sostavlyayuschego prirodnyih resursov. Fundamentalnyie issledovaniya. 2008. № 2. S. 130-132. 6. Onyshchuk S., Buryk Z., Knysh P. Management of the economic potential of territories in the context of sustainable development: case of Ukraine Problems and perspectives in management. Business perspectives. 2019. Volume 17, Issue 4. Pp. 1325. 7. Plyuta V. Sravnitelnyiy mnogomernyiy analiz $v$ ekonomicheskih issledovaniyah / per. s polsk. V. V. Ivanova. M. : Finansyi i statistika, 1989. 174 s. 8. Didkivska T. V., Sverchevska I. A. Uzahalnennia zolotoi systemy chyslennia. Visn. Zhytomyr. derzh. ped. un-tu. 2003. № 11. S. 36-39. 9. Davydiuk 0. 0. Sotsialna bezpeka: problemy teoretychnoho analizu ta pobudovy systemnykh pokaznykiv. URL: http://www.cpsr.org.ua/ (data zvernennia: 20.05.2020). 10. Indykatory stanu ekolohichnoi bezpeky derzhavy. Analitychna zapyska. URL: http://old2.niss.gov.ua/articles/993. (data zvernennia: 20.05.2020). 11. Pavlova 0. M., Kupchak V. R., Pavlov K. V., Lahodiienko V. V. Formuvannia ta rehuliuvannia rehionalnykh enerhetychnykh system: teoriia, metodolohiia ta praktyka : monohrafiia. Lutsk : SPD Hadiak Zhanna Volodymyrivna, drukarnia «Volynpolihraf», 2019. 346 s. 12. Pavlov K. V., Pavlova O. M., Korotia M. I. Rehuliuvannia diialnosti rehionalnykh hazorozpodilnykh pidpryiemstv Ukrainy : monohrafiia. Lutsk : SPD Hadiak Zhanna Volodymyrivna, drukarnia «Volynpolihraf», 2020. 256 s. 13. Pavlov K., Pavlova 0., Kupchak V. Integral Indicators Based on Competitiveness Capacity Characteristics of Regional Real Estate Markets of Ukraine. Journal of Competitiveness. 2019. № 11(3). S. 87-108 https ://doi.org/10.7441/joc.2019.03.06 (data zvernennia: 20.05.2020).

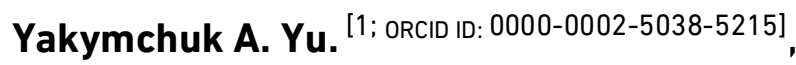
Doctor of Economics, Professor of Department of Public Administration, Documentation and Informational Activity,

Kardash O. L. [1; ORCID ID: 0000-0002-6531-9165], Candidate of Economics (Ph.D.), Associate Professor, Associate Professor of the Department of Computer Technology and Economic

Cybernetics,

Yakymchuk O. F. [2; ORCID ID: 0000-0002-0960-8835], Candidate of Public Administration (Ph.D.), Head of The Group of Calculations of the Business Systems Department

\author{
${ }^{1}$ National University of Water and Environmental Engineering, Rivne Rivne Regional \\ ${ }^{2}$ Energy Supply Company, Rivne
}




\section{ASSESSMENT OF THE ECOLOGICAL SAFETY OF UKRAINE BASED ON TAXONOMIC ANALYSIS}

The concept of sustainable development is guaranteed to be safe for the life and health of the population environment. Environmental assessment is confirmed by the analysis of the actual indicators of environmental safety conducted in this scientific study. Special attention has been given to such important indicators of ecological safety, as reforestation, implementation of resource-saving, low-cost, non-waste innovation by the industrial enterprises of Ukraine, costs of biodiversity preservation and habitat, etc. The ways of disadvantages elimination in the methodology of environmental safety indicators have been suggested. The state of environmental security in the European Union countries has been analyzed and new tendencies of its improvement on the national level have been determined according to the concept of sustainable development. The substantiation and analysis of main indicators of ecological safety have been carried out, in order to conduct the indicators to the dimensionality the standardization has been performed, taking into account the nature of their influence on the integral indicator of security. This article discusses the prospects of increasing the level of ecological safety of Ukraine in accordance with European standards. According to the results, the dynamics of the level of environmental safety indicator of Ukraine in the years 20082019 is rather unstable, dominated by significant fluctuations in values and peak reductions for a number of years during the period of study. This situation has been caused by the significant anthropogenic load on the environment, the high level of pollutant emissions into the atmospheric air and discharges into water objects, large areas of deforestation.

Keywords: state, ecology safety, natural resources, international activity, sustainable development, integrated indicator, taxonomic analysis.

Якимчук А. Ю. ${ }^{[1 ; 0 R C I D ~ I D: ~ 0000-0002-5038-5215], ~}$ д.э.н., профессор, профессор кафедры государственного управления, документоведения и информационной деятельности

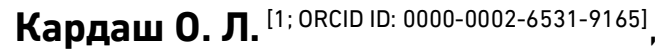
к.э.н., доцент, доцент кафедры компьютерных технологий и экономической кибернетики

Якимчук О. Ф. [2; ORCID ID: 0000-0002-0960-8835], к.гос.упр., руководитель группы расчетов

\footnotetext{
${ }^{1}$ Национальный университет водного хозяйства и природопользования, г. Ровно

${ }^{2}$ ТОО «Ровенская энергопоставочная компания», г. Ровно
} 


\section{ОЦЕНКА ЭКОЛОГИЧЕСКОЙ БЕЗОПАСНОСТИ УКРАИНЫ НА ОСНОВЕ ТАКСОНОМИЧЕСКОГО АНАЛИЗА}

Концепция устойчивого развития гарантированно будет безопасной для жизни и здоровья населения. Экологическая оценка подтверждается анализом фактических показателей, проведенным в данном научном исследовании. Особое внимание уделяется таким важным показателям экологической безопасности, как лесовосстановление, реализация ресурсосберегающих, недорогих, неотходных инноваций промышленными предприятиями Украины, затраты на сохранение биоразнообразия и среды обитания и т.д. Предлагаются пути устранения недостатков в методологии показателей экологической безопасности. Было проанализировано состояние экологической безопасности в странах Европейского Союза, и в соответствии с концепцией устойчивого развития определяются новые тенденции его совершенствования на национальном уровне. Проведены обоснование и анализ основных показателей экологической безопасности. С сопоставлением показателей по размерности была проведена стандартизация с учетом характера их влияния на интегральный показатель экологической безопасности. В статье предложены перспективы повышения уровня экологической безопасности Украины в соответствии с европейскими нормами и стандартами.

Ключевые слова: государство; экологическая безопасность; природные ресурсы; международное сотрудничество; устойчивое развитие; интегральный індикатор; таксономический анализ. 